\section{Single and Multiple Modes of Action Insecticides for Control of Asian Citrus Psyllid and Citrus Leafminer}

\author{
Jawwad A. Qureshi ${ }^{1,2}$, Barry C. Kostyk, and Philip A. Stansly \\ Department of Entomology and Nematology, Southwest Florida Research \\ and Education Center, University of Florida/IFAS, Immokalee, FL 34142
} Additional index words. chemical control, Citrus sinensis, citrus greening disease, citrus
canker, Diaphorina citri, huanglongbing, Phyllocnistis citrella

\begin{abstract}
Control of Asian citrus psyllid Diaphorina citri Kuwayama and citrus leafminer Phyllocnistis citrella Stainton is important to reduce the spread and severity of huanglongbing (HLB) (citrus greening) and citrus canker diseases, respectively. Insecticides are critical for the management of these pests. We therefore conducted two replicated experiments using spray treatments containing single or multiple modes of action (MoA) insecticides to reduce the incidence of these two pests in bearing citrus. Tank mixing in $47 \mathrm{~L} \cdot \mathrm{ha}^{-1}$ ( $5 \mathrm{gal} / \mathrm{acre}$ ) of water with synthetic plant terpenes (Requiem 25 EC, Unknown MoA) or adjuvant petroleum oil (PureSpray Green, Unknown MoA) did not improve the effectiveness of the pyrethroid zeta-cypermethrin (Mustang Max 0.15 EC, MoA 3A) against D. citri. Its control with flupyradifurone (Sivanto $200 \mathrm{SL}$ MoA 4D) and PureSpray Green in $935 \mathrm{~L} \cdot \mathrm{ha}^{-1}$ (100 gal/ acre) water was similar to Mustang Max 0.15 EC and Requiem 25 EC, but mixtures did not provide better control than Mustang Max 0.15 EC alone. Phyllocnistis citrella was controlled only with Sivanto 200 SL and PureSpray Green and Requiem 25 EC alone. The addition of cyantraniliprole (group $28 \mathrm{MoA}$ in A16971 premixed with thiamethoxam MoA 4A), pymetrozine (Fulfill 50 WDG, MoA 9B), or abamectin (Agri-Mek SC, MoA 6) did not improve and in many cases reduced the performance of thiamethoxam (Actara 25 WG, MoA 4A) against $D$. citri and $P$. citrella. These results demonstrated no advantage to single applications of multiple MoAs over the most effective active ingredients when applied alone for control of $D$. citri or $P$. citrella. Therefore, rotations of these active ingredients would be preferable to mixtures to avoid selection for resistance against multiple MoAs by any one application.
\end{abstract}

The Asian citrus psyllid Diaphorina citri Kuwayama (Hemiptera: Liviidae) and citrus leafminer Phyllocnistis citrella Stainton (Lepidoptera: Gracillariidae) are two important pests of citrus. Diaphorina citri vectors putative pathogens of HLB or citrus greening disease (Halbert and Manjunath, 2004). Nymphs are considered more efficient at acquisition and adults at the transmission and spread of these pathogens. Feeding damage by the larvae of $P$. citrella exacerbates the spread of citrus canker disease, another serious threat to the citrus industry (Chagas et al., 2001; Sohi and Sandhu, 1968). Control of $D$. citri and $P$. citrella is critical because related diseases are now endemic in Florida.

Most insecticide applications in Florida citrus target $D$. citri because of the severity and devastation of HLB. Soil drenches of neonicotinoid insecticides, with MoA 4A and cyantraniliprole (MoA 28), provide extended protection from $D$. citri and $P$. citrella lasting

Received for publication 4 Jan. 2017. Accepted for publication 12 Apr. 2017

This research was originally presented at the 2016 annual meeting of the Florida State Horticultural Society.

${ }^{1}$ Current address: Indian River Research and Education Center, Fort Pierce, FL 34945.

${ }^{2}$ Corresponding author. E-mail: jawwadq@uff.edu.
6-8 weeks, but are limited to young trees because of rate restrictions (Qureshi et al., 2014a; Rogers and Shawer, 2007; Stansly and Kostyk, 2012, 2013, 2014). Both D. citri and $P$. citrella need developing shoots (flush) to develop and reproduce. However, mature trees generally do not flush in winter. Sprays of broad-spectrum insecticides in winter have been shown to provide significant suppression of overwintering $D$. citri, reducing numbers accessing spring growth, and are used areawide (Qureshi and Stansly, 2010a; Stansly et al., 2009). Phyllocnistis citrella is thought to overwinter as larvae or pupae in scarce flush when most trees are not producing new growth attractive to both the pests to develop and 2006; Qureshi et al., 2009). During the growing season, trees produce new growth used by both species to reproduce and increase their populations. Several natural enemies of D. citri and $P$. citrella are also common during the growing season and contribute to their control (Qureshi and Stansly, 2009, 2010a; Xiao et al., 2007). However, additional measures to control both $D$. citri and $P$. citrella are warranted.

Sprays of insecticides have greatly increased in Florida since the advent of HLB to reduce populations of $D$. citri as well as other pests such as $P$. citrella (Monzo and Stansly, 2015; Rogers et al., 2014). The increased use of insecticides has negatively reproduce (Hall and Albrigo, 2007; Lim et al., impacted biological control which has always been an important component of citrus insect pest management in Florida and other regions (McCoy, 1985; Michaud, 2004; Monzo et al., 2014; Qureshi and Stansly, 2007, 2009, 2010a, 2010b; Qureshi et al., 2014b; Van den Berg et al., 1992), resulting in increases in secondary pest outbreaks. Such intense use of insecticides may also accelerate selection for pest resistance already documented in some studies (Kanga et al., 2014; Tiwari et al., 2011)

Insecticidal sprays used against $D$. citri contain single or multiple MoA toxins. The latter is achieved by using premixed products or tank mixing multiple products with different MoAs to enhance efficacy and target multiple pests. However, it is important to investigate the effectiveness of the single and multiple MoA treatments for their impact on the populations of $D$. citri and other pests such as $P$. citrella. Low-volume applications tested here have been used for $D$. citri control in Florida but with variable results depending, in part, on the product tested (Attwood and Stelinski, 2008; Qureshi et al., 2014a). Findings are reported from the experiments designed to evaluate the effectiveness of labeled and experimental insecticides sprayed alone and in mixtures against $D$. citri and $P$. citrella.

\section{Materials and Methods}

Two experiments were conducted in the citrus orchards during the growing season to assess the lethal effects of foliar sprays containing single MoA insecticides, multiple MoA insecticides, or both premixed or tank mixed for control of $D$. citri and $P$. citrella. Information on the chemicals, their MoAs, and manufacturers is provided in Table 1.

Experiment 1. The experiment was conducted in a block of 6-year-old sweet orange Citrus sinensis (L.) Osbeck 'Valencia' and 'Hamlin' orange trees planted at a density of 326 trees/ha (132 trees/acre) at the Southwest Florida Research and Education Center in Immokalee, FL. Seven spray treatments containing one or two insecticides (Table 2) and an untreated control were assigned to a randomized complete block design (RCBD) with four replicates in seven-tree plots over four rows separated by two untreated buffer rows. There was one untreated buffer tree between treatment plots within a row. Treatments were applied on 3 June 2014 to both sides of the trees. Five treatments were applied at low volume using a Proptec rotary atomizer sprayer operating at $5 \mathrm{mph}$ and equipped with a peristaltic pump delivering a final application volume at $47 \mathrm{~L} \cdot \mathrm{ha}^{-1}$ (5 gal/acre). Ground and aerial applications against $D$. citri are becoming more and more common in Florida. The two high-volume treatments were applied at $935 \mathrm{~L} \cdot \mathrm{ha}^{-1}$ (100 gal/acre) using a Durand Wayland AF100-32 air blast speed sprayer operating at $1.9 \mathrm{mph}$ and $350 \mathrm{psi}$ equipped with four John Bean ceramic nozzles no. 4, 4, 4, 2.5 on each side. Ten randomly selected shoots per plot were collected and examined under a stereomicroscope 
in the laboratory to count dead and live $D$. citri nymphs, and three fully expanded leaves on each shoot were examined to count $P$. citrella larvae at 3, 7, 14, 20, and $27 \mathrm{~d}$ after treatment (DAT). Density of D. citri adults was estimated using a "stem tap" sample taken from each of the six central trees in each plot on the above dates and 34 and 41 DAT. Adults were counted that fell on a clipboard covered with a $22 \times 28 \mathrm{~cm}\left(8 \frac{1}{2} \times 11\right.$ inches $)$ laminated white sheet held horizontally under randomly chosen branches which were struck three times with a length of PVC pipe (Qureshi and Stansly, 2007; Qureshi et al., 2009). Two tap samples were conducted per tree on each observation.

Experiment 2. This experiment was conducted in a commercial grove near LaBelle, FL. The experimental block consisted of 7-year-old sweet orange Citrus sinensis (L.) Osbeck 'Hamlin' trees planted at a density of 326 trees/ha (132 trees/acre). Five spray treatments of single or multiple MoA insecticides (Table 4) and an untreated control were randomly distributed in an RCBD with four replicates in five-tree plots over four rows separated by one untreated buffer row. There was one untreated buffer tree between treatment plots within a row. Treatments were applied on 12 Aug. 2014 to both sides of the trees with a Durand Wayland AF100-32 air blast speed sprayer operating at $1.9 \mathrm{mph}$ and 350 psi equipped with three John Bean ceramic nozzles $3,4,5$ on each side delivering final application volume at $935 \mathrm{~L} \cdot \mathrm{ha}^{-1}$
(100 gal/acre). Sampling was conducted at $3,7,14,21$, and 28 DAT using the procedure described in experiment 1 except that four tap samples were conducted per tree on three trees per plot because of less number of total trees per plot.

Data were analyzed using SAS Systems for Windows, version 9.4 (SAS Institute, 2012). The Shapiro-Wilk W test and normality plots did not validate the assumptions of parametric analysis using the Univariate procedure. Data were log transformed to reduce heterogeneity of variances and analyzed by using the nonparametric Kruskal-Wallis test at $P<0.05$ for significant effects. Actual means are presented.

\section{Results}

Experiment 1. Effects of treatments on Diaphorina citri and Phyllocnistis citrella. There was no significant difference in dead nymphs between treatments of Mustang Max $0.15 \mathrm{EC}$ alone and Mustang Max 0.15 EC plus Requiem $25 \mathrm{EC}$ at $3 \mathrm{DAT}$; however, significantly more dead $D$. citri nymphs compared with the untreated control were observed with all treatments $\left(\chi^{2}=57.23, d f=7, P<0.0001\right)$ (Table 2). In contrast, no more dead nymphs than the untreated control were found as a result of any treatments that included Requiem 25 EC at 7 DAT and less with Mustang Max 0.15 EC plus Requiem 25 EC than Mustang Max 0.15 EC alone $\left(\chi^{2}=24.04, d f=7, P=0.0011\right)$. The number of live nymphs did not differ significantly between treatments of Mustang Max 0.15 EC alone and Mustang Max 0.15 EC plus Requiem 25 EC; however, fewer were observed in response to all treatments compared with the untreated control on all sample dates through 27 DAT $\left(\chi^{2}=41.90\right.$, $d f=7, P<0.0001)$ except for Requiem $25 \mathrm{EC}$ alone at either volume after 7 DAT.

Treatment effects on $P$. citrella populations were significant at 3 DAT $\left(\chi^{2}=64.08\right.$, $d f=7, P<0.0001)$ and 7 DAT $\left(\chi^{2}=26.01\right.$, $d f=7, P=0.0005)$ although only Sivanto 200 SL plus PureSpray Green and Requiem 25 EC applied alone at high volume provided significant reduction in larvae compared with the untreated control at either 3 or 7 DAT (Table 2).

Significant reduction in adult $D$. citri populations was observed with all treatments compared with the untreated control at all observation dates from 7 through 27 DAT $\left(\chi^{2}=24.40, d f=7, P<0.0010\right.$, Table 3$)$ except at 3 DAT for Requiem $25 \mathrm{EC}$ alone at either volume or with Mustang Max 0.15 EC and at 14 DAT for Requiem 25 EC alone at low volume. Overall treatment effect was still significant at 34 DAT $\left(\chi^{2}=24.97, d f=7, P=\right.$ 0.0008 ), but only Mustang Max 0.15 EC plus Requiem $25 \mathrm{EC}$ at either rate and Sivanto 200 SL plus PureSpray Green were providing reduction compared with the untreated control. However, tank mixing with Requiem $25 \mathrm{EC}$ or PureSpray Green did not improve the effectiveness of Mustang Max 0.15 EC on any date. No phytotoxicity was observed with any treatment.

Table 1. Details of insecticides and adjuvants sprayed on citrus trees infested with Diaphorina citri Kuwayama and Phyllocnistis citrella Stainton.

\begin{tabular}{llll}
\hline Brand name formulation (I, A) $)^{\mathrm{z}}$ & \multicolumn{1}{c}{ Chemical name } & IRAC MoA $\mathrm{A}^{\mathrm{y}}$ & \multicolumn{1}{c}{ Manufacturer } \\
\hline Mustang Max 0.15 EC (I) & Zeta-cypermethrin & 3A & FMC Corporation (PA) \\
Requiem 25 EC (I) & Chenopodium & Unknown & Bayer CropScience (NC) \\
Sivanto 200 SL (I) & Flupyradifurone & 4D & Bayer CropScience (NC) \\
PureSpray Green (A) & petroleum oil & Unknown & Petro-Canada (ON) \\
Fulfill 50 WDG (I) & Pymetrozine & $9 \mathrm{~B}$ & Syngenta Crop Protection (NC) \\
Agri-Mek SC (I) & Abamectin & 6 & Syngenta Crop Protection (NC) \\
Actara 25 WG (I) & Thiamethoxam & $4 \mathrm{~A}$ & Syngenta Crop Protection (NC) \\
A16971 $(\mathrm{I})$ & Thiamethoxam + cyantraniliprole & 4A + 28 & Syngenta Crop Protection (NC) \\
Dyne-Amic (A) & Nonionic surfactant & Unknown & Helena Chemical Company (TN) \\
\hline
\end{tabular}

${ }_{\mathrm{Z}} \mathrm{I}=$ insecticide, $\mathrm{A}=$ adjuvant.

${ }^{\mathrm{y}}$ Insecticide Resistance Action Committee, Mode of Action, http://www.irac-online.org/.

${ }^{\mathrm{x}}$ Experimental premix.

Table 2. Mean number of Diaphorina citri Kuwayama nymphs and Phyllocnistis citrella Stainton larvae per shoot in 6-year-old 'Valencia' and 'Hamlin' orange trees that were untreated or treated with foliar sprays containing single or multiple Mode of Action insecticides and adjuvants on 3 June 2014 at Southwest Florida Research and Education Center, Immokalee, FL.

\begin{tabular}{|c|c|c|c|c|c|c|c|c|c|c|c|}
\hline \multirow[b]{2}{*}{ Treatment/formulation } & \multirow{2}{*}{$\begin{array}{l}\text { Rate L } \cdot \text { ha }^{-1} \\
\text { (oz/acre) }\end{array}$} & \multirow{2}{*}{$\begin{array}{l}\text { Application } \\
\text { volume } \mathrm{L} \cdot \mathrm{ha}^{-1} \\
\text { (gal } / \text { acre })\end{array}$} & \multicolumn{2}{|c|}{$\begin{array}{c}\text { D. citri dead } \\
\text { nymphs/shoot } \\
\text { days after treatment }\end{array}$} & \multicolumn{4}{|c|}{$\begin{array}{l}\text { D. citri live nymphs/shoot } \\
\text { days after treatment }\end{array}$} & \multirow[b]{2}{*}{27} & \multicolumn{2}{|c|}{$\begin{array}{c}\text { P. citrella } \\
\text { larvae/shoot } \\
\text { days after treatment }\end{array}$} \\
\hline & & & 3 & 7 & 3 & 7 & 14 & 20 & & 3 & 7 \\
\hline Untreated control & & & $0.08 \mathrm{c}$ & $0.05 \mathrm{~d}$ & $6.60 \mathrm{a}$ & $10.88 \mathrm{a}$ & $9.13 \mathrm{a}$ & $12.05 \mathrm{~b}$ & $8.90 \mathrm{a}$ & $1.28 \mathrm{a}$ & $1.23 \mathrm{a}$ \\
\hline Mustang Max 0.15 EC & $0.3(4)$ & $47(5)$ & $4.93 \mathrm{a}$ & $2.50 \mathrm{a}$ & $2.05 \mathrm{bc}$ & $2.25 \mathrm{~d}$ & $0.43 \mathrm{cb}$ & $4.55 \mathrm{c}$ & $0.37 \mathrm{c}$ & $1.42 \mathrm{a}$ & $1.05 \mathrm{a}$ \\
\hline $\begin{array}{l}\text { Mustang Max 0.15 EC + } \\
\text { PureSpray Green }\end{array}$ & $0.3+9.3(4+128)$ & $47(5)$ & $6.98 \mathrm{a}$ & $1.80 \mathrm{abc}$ & $2.03 \mathrm{bc}$ & $10.40 \mathrm{ab}$ & $1.50 \mathrm{cb}$ & $3.12 \mathrm{c}$ & $0.75 \mathrm{c}$ & $1.28 \mathrm{a}$ & $0.88 \mathrm{a}$ \\
\hline $\begin{array}{l}\text { Mustang Max 0.15 EC + } \\
\text { Requiem 25 EC }\end{array}$ & $0.3+4.7(4+64)$ & $47(5)$ & $8.05 \mathrm{a}$ & $1.00 \mathrm{~cd}$ & $2.00 \mathrm{bc}$ & $0.30 \mathrm{e}$ & $0.75 \mathrm{cb}$ & $2.40 \mathrm{c}$ & $1.14 \mathrm{c}$ & $1.10 \mathrm{a}$ & $1.13 \mathrm{a}$ \\
\hline Requiem $25 \mathrm{EC}$ & $4.7(64)$ & $935(100)$ & $4.73 \mathrm{ab}$ & $0.73 \mathrm{bcd}$ & $3.13 \mathrm{~b}$ & $2.65 \mathrm{de}$ & $7.65 \mathrm{a}$ & $22.75 \mathrm{a}$ & $4.10 \mathrm{ab}$ & $0.25 \mathrm{~b}$ & $0.50 \mathrm{~b}$ \\
\hline $\begin{array}{l}\text { Sivanto } 200 \mathrm{SL}+ \\
\quad \text { PureSpray Green } \\
\end{array}$ & $0.7+9.3(10+128)$ & $935(100)$ & $6.45 \mathrm{a}$ & $1.60 \mathrm{ab}$ & $0.70 \mathrm{c}$ & $2.45 \mathrm{de}$ & $1.93 \mathrm{~b}$ & $2.50 \mathrm{c}$ & $4.53 \mathrm{bc}$ & $0.10 \mathrm{~b}$ & $0.40 \mathrm{~b}$ \\
\hline
\end{tabular}

Means in a column sharing common letters are not significantly different $(P>0.05)$. 
Experiment 2. Effects of treatments on Diaphorina citri and Phyllocnistis citrella. Significant reduction of live $D$. citri nymphs was observed with all treatments on all observation days through 14 DAT $\left(\chi^{2}=\right.$ 68.43, $d f=5, P<0.0001)$ except at 14 DAT for the only treatment that did not include thiamethoxam: Fulfill 50 WDG 0.4 $\mathrm{L} \cdot \mathrm{ha}^{-1}$ (5.5 oz/acre) (Table 4). None of the mixed treatments provided better control of nymphs compared with thiamethoxam (Actara 25 WG $0.4 \mathrm{~L} \cdot \mathrm{ha}^{-1}, 5.5 \mathrm{oz} /$ acre) alone. Similar treatment effects were seen against adults with Fulfill 50 WDG alone being the weakest treatment, and none were better than thiamethoxam (Actara $25 \mathrm{WG}$ ) alone which was the only treatment still effective at 28 DAT $\left(\chi^{2}=14.18, d f=5, P=0.0145\right)$.

All treatments significantly reduced $P$. citrella compared with the untreated control through 14 DAT $\left(\chi^{2}=100.45, d f=5, P<\right.$ 0.0001 ) except Fulfill 50 WDG alone at 7 DAT which also provided significantly less reduction compared with other treatments. There was no improvement in control over thiamethoxam (Actara $25 \mathrm{WG}$ ) alone with any mixture containing two or more MoAs. No phytotoxicity was observed in any treatment.

\section{Discussion}

Findings from both experiments demonstrated that there was little or no advantage to single-spray applications of multiple MoA insecticides tested over the most effective single MoA active ingredients sprayed alone for control of $D$. citri or $P$. citrella. Tank mixing with synthetic plant terpenes (Requiem $25 \mathrm{EC}$, Unknown MoA) did not improve the performance of the pyrethroid zeta-cypermethrin (Mustang Max 0.15 EC, MoA 3A) against D. citri and $P$. citrella except 1 week prolonged reduction of adult D. citri. The direct effects on nymphs are measurable for 2-3 weeks which is the time it takes for new shoots to mature and nymphs to develop into adults. The slightly prolonged effect of mixed insecticide treatments on adults compared with single insecticide could be carryover from the earlier suppression of nymphs. Petroleum-based horticultural mineral oil is a commonly used adjuvant which, when applied alone, also provides considerable control of $D$. citri and several other pests such as $P$. citrella, orange spiny whitefly, Aleurocanthus spiniferus (Quaintance), red scale, Aonidiella aurantii (Maskell) (Hemiptera: Diaspididae), and chaff scale, Parlatoria pergandii Comstock (Hemiptera: Aleyrodidae) (Beattie et al., 2000; Davidson, 1991; Qureshi et al., 2014a; Rae et al., 1996, 1997; Tansey et al., 2015). Neither petroleum oil (PureSpray Green) nor Requiem significantly improved the performance of Mustang Max 0.15 EC against $D$. citri. Furthermore, Mustang seemed to interfere with control exerted by Requiem against $P$. citrella, which was lost when the two products were mixed.
All treatments in the second experiment were applied with Dyne-Amic nonionic surfactant which contains highly refined methylated seed oils and specialized organosilicone particles to provide effective penetration and coverage. However, the effectiveness of thiamethoxam (MoA 4A) against $D$. citri and $P$. citrella was not improved, and was even reduced, by premixing with cyantraniliprole (MoA 28) in A16971 or tank mixing with pymetrozine (Fulfill 50 WDG, MoA 9B) or abamectin (Agri-Mek SC, MoA 6). Therefore, we saw nothing gained by the tank or premixes evaluated in these trials, which furthermore incurred the additional disadvantage of exposing pest populations to multiple MoAs and thus limiting.

Insecticide resistance is a serious concern and already reported in $D$. citri against some effective MoAs (Kanga et al., 2014; Tiwari et al., 2011). Therefore, rotations of effective active ingredients would be preferable to mixtures to avoid selection for resistance against multiple MoAs by any one application. Such rotations may also use selective insecticides to help conserve the most effective MoAs (Qureshi et al., 2013; Rae et al., 1997; Tansey et al., 2015) and biological control which may suffer more mortality of predators and parasitoids from the use of multiple MoAs at one time compared with single MoA rotation over time (Qureshi and Stansly 2009, 2010a). These considerations

Table 3. Mean number of Diaphorina citri Kuwayama adults per tap sample in 6-year-old 'Valencia' and 'Hamlin' orange trees that were untreated or treated with foliar sprays containing single or multiple Mode of Action insecticides and adjuvants on 3 June 2014 at Southwest Florida Research and Education Center, Immokalee, FL.

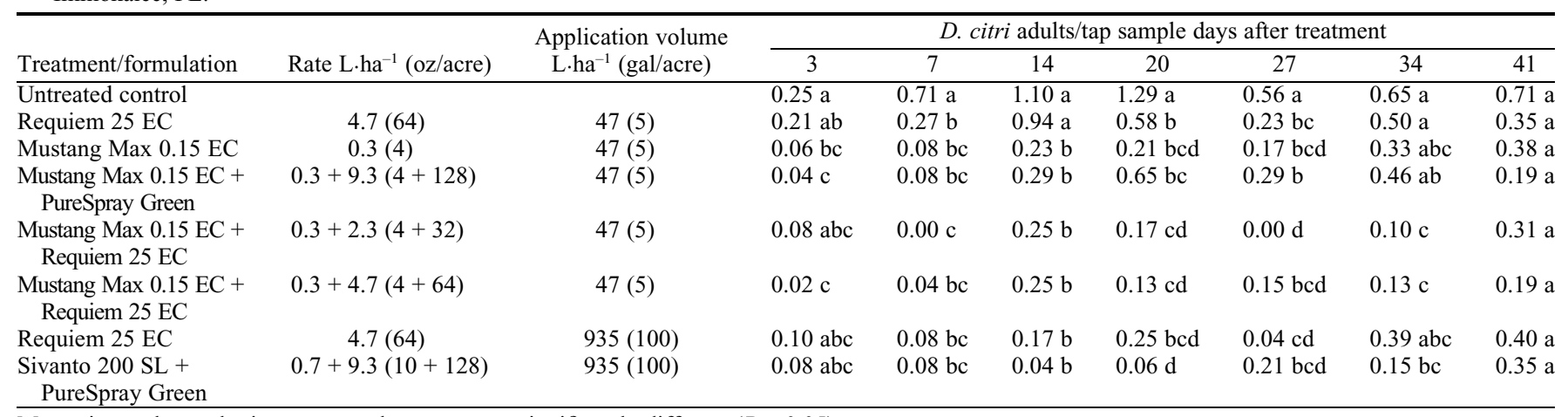

Means in a column sharing common letters are not significantly different $(P>0.05)$.

Table 4. Mean number of Diaphorina citri Kuwayama nymphs per shoot, adults per tap sample, and Phyllocnistis citrella Stainton larvae per shoot in 7-year-old 'Hamlin' orange trees that were untreated or treated with foliar sprays containing single or multiple Mode of Action insecticides and adjuvants on 12 Aug. 2014 at a commercial grove near LaBelle, FL.

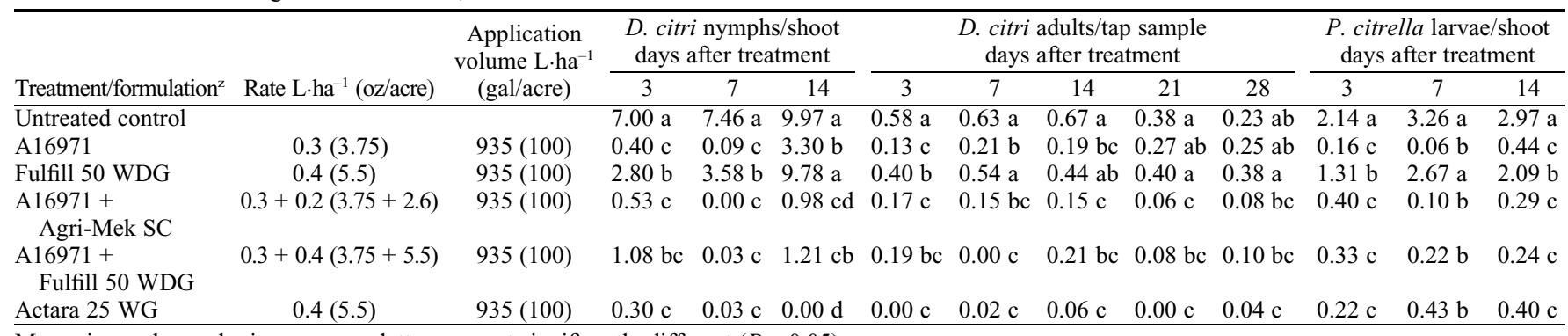

Means in a column sharing common letters are not significantly different $(P>0.05)$.

${ }^{\mathrm{z}}$ All treatments were applied with Dyne-Amic, a nonionic surfactant at $0.9 \mathrm{~L} \cdot \mathrm{ha}^{-1}(32 \mathrm{oz} / \mathrm{acre})$. 
are important for developing integrated and sustainable pest management programs.

\section{Literature Cited}

Attwood, R. and L. Stelinski. 2008. Evaluation of low volume application technologies for Asian citrus psyllid (Diaphorina citri Kuwayama) control. Proc. Annu. Meet. Fla. State Hort. Soc. 121:110-112.

Beattie, G.A.C., A.D. Clift, R.A. Parkes, and L. Jiang. 2000. Impacts of spray volume and horticultural mineral oil concentration on control of pink wax scale and red scale in citrus orchards, p. 582-591. In: G.A.C. Beattie, D.M. Watson, M.L. Stevens, D.J. Rae, and R.N. Spooner-Hart (eds.). Spray oils beyond 2000, Univ. of Western Sydney, New South Wales, Australia.

Chagas, M.C.M., J.R.P. Parra, T. Namekata, J.S Hartung, and P.T. Yamamoto. 2001. Phyllocnistis citrella Stainton (Lepidoptera: Gracillariidae) and its relationship with the citrus canker bacterium Xanthomonas axonopodis pv. citri in Brazil. Neotrop. Entomol. 30:55-59.

Davidson, N.A. 1991. Statewide Integrated Pest Management Project. Managing insects and mites with spray oils. Publication/IPM Education and Publications. Univ. of California, Division of Agriculture and Natural Resources, (USA).

Halbert, S.E. and K.L. Manjunath. 2004. Asian citrus psyllids (Sternorrhyncha: Psyllidae) and greening disease of citrus: A literature review and assessment of risk in Florida. Fla. Entomol. 87:330-353.

Hall, D.G. and L.G. Albrigo. 2007. Estimating the relative abundance of flush shoots in citrus with implications on monitoring insects associated with flush. HortScience 42:364-368.

Kanga, L.H.B., J. Eason, M. Haseeb, J.A. Qureshi, and P.A. Stansly. 2014. Monitoring for insecticide resistance in Asian citrus psyllid (Hemiptera: Psyllidae) populations in Florida. J. Econ. Entomol. 109:832-836.

Lim, U.T., L. Zappalá, and M.A. Hoy. 2006. Prerelease evaluation of Semielacher petiolatus (Hymenoptera: Eulophidae) in quarantine for the control of citrus leafminer: Host discrimination, relative humidity tolerance and alternative hosts. Biol. Control 36:65-73.

McCoy, C.W. 1985. Citrus: Current status of biological control in Florida, p. 481-499. In: M.A. Hoy and D.C. Herzog (eds.). Biological control in agricultural IPM systems, Academic, Orlando, FL.

Michaud, J.P. 2004. Natural mortality of Asian citrus psyllid (Homoptera: Psyllidae) in central Florida. Biol. Control 29:260-269.

Monzo, C., J.A. Qureshi, and P.A. Stansly. 2014. Insecticide sprays, natural enemy assemblages and predation on Asian citrus psyllid, Diaphorina citri K. (Hemiptera: Liviidae). Bull. Entomol. Res. 104:576-585.

Monzo, C. and P.A. Stansly. 2015. Thresholds for vector control and compatibility with beneficial fauna in citrus with high incidence of Huanglongbing, p. 1137-1144. In: Proceedings XIIth Intl. Citrus Congress. Acta Hort. 1065 , ISHS.

Qureshi, J.A., B.C. Kostyk, and P.A. Stansly. 2013. Control of Asian citrus psyllid and citrus leafminer in oranges with foliar sprays of horticultural mineral oil, microbial and synthetic insecticides. Proc. Annu. Meet. Fla. State Hort. Soc. 126:62-67.

Qureshi, J.A., B.C. Kostyk, and P.A. Stansly. 2014a. Insecticidal Suppression of Asian Citrus Psyllid Diaphorina citri (Hemiptera: Liviidae) Vector of Huanglongbing Pathogens. PLoS One 9(12):E112331, doi: 10.1371/journal.pone. 0112331.

Qureshi, J.A., M.E. Rogers, D.G. Hall, and P.A. Stansly. 2009. Incidence of invasive Diaphorina citri (Homoptera: Psyllidae) and its introduced parasitoid Tamarixia radiata (Hymenoptera: Eulophidae) in citrus groves of Florida. J. Econ. Entomol. 102:247-256.

Qureshi, J.A., E. Rohrig, R. Stuart, D.G. Hall, N.C. Leppla, and P.A. Stansly. 2014b. Imported parasitoids for biological control of Asian citrus psyllid. Citrus Indust. 95:10-13.

Qureshi, J.A. and P.A. Stansly. 2007. Integrated approaches for managing the Asian citrus psyllid Diaphorina citri (Homoptera: Psyllidae) in Florida. Proc. Annu. Meet. Fla. State Hort. Soc. 120:110-115.

Qureshi, J.A. and P.A. Stansly. 2009. Exclusion techniques reveal significant biotic mortality suffered by Asian citrus psyllid Diaphorina citri (Hemiptera:Psyllidae) populations in Florida citrus. Biol. Control 50:129-136.

Qureshi, J.A. and P.A. Stansly. 2010a. Dormant season foliar sprays of broad-spectrum insecticides: An effective component of integrated management for Diaphorina citri (Hemiptera: Psyllidae) in citrus orchards. Crop Prot. 29: 860-866.

Qureshi, J.A. and P.A. Stansly. 2010b. Tamarixia radiata Waterston [Hymenoptera: Eulophidae], an ectoparasitoid of Diaphorina citri Kuwayama [Hemiptera: Psyllidae]. 12 Mar. 2014. <http://www.nysaes.cornell.edu/ent/ biocontrol/parasitoids/Tamarixia.html $>$.

Rae, D.J., G.A.C. Beattie, D.M. Watson, Z.M. Liu, and L. Jiang. 1996. Effects of petroleum spray oils without and with copper fungicides on the control of citrus leaf miner, Phyllocnistis citrella Stainton (Lepidoptera: Gracillariidae). Austral. J. Entomol. 35:247-251.

Rae, D.J., W.G. Liang, D.M. Watson, G.A.C. Beattie, and M.D. Huang. 1997. Evaluation of petroleum spray oils for control of the Asian citrus psylla, Diaphorina citri (Kuwayama) (Hemiptera: Psyllidae), in China. Intl. J. Pest Mgt. 43:71-75.

Rogers, M.E. and D.B. Shawer. 2007. Effectiveness of several soil-applied systemic insecticides for managing the Asian citrus psyllid, Diaphorina citri Kuwayama (Homoptera: Psy1lidae). Proc. Annu. Meet. Fla. State Hort. Soc. 120:116-119.

Rogers, M.E., P.A. Stansly, and L.L. Stelinski. 2014. Florida citrus pest management guide: Asian citrus psyllid and citrus leafminer. 19 May 2017. $<$ http://edis.ifas.ufl.edu>. ENY-734.

SAS Institute. 2012. SAS for windows, version 9.3. SAS Inst., Cary, NC.

Sohi, G.S. and M.S. Sandhu. 1968. Relationship between citrus leaf-miner (Phyllocnistis citrella Stainton) injury and citrus canker [Xanthomonas citri (Hasse) Dowson] incidence on citrus leaves. J. Res. Punj. Agr. Univ. 5:66-69.

Stansly, P.A., H.A. Arevalo, M. Zekri, and R. Hamel. 2009. Cooperative dormant spray program against Asian citrus psyllid in SW Florida. Citrus Indust. 90:14-15.

Stansly, P.A. and B.C. Kostyk. 2012. Soil applied insecticidal control of Asian citrus psyllid and citrus leafminer, 2010. Arthrop. Mgt. Tests 37, doi: 10.4182/amt.2012.D15.

Stansly, P.A. and B.C. Kostyk. 2013. Soil drench applications for control of Asian citrus psyllid and citrus leafminer, 2012. Arthrop. Mgt. Tests 38, doi: 10.4182/amt.2013.D15.

Stansly, P.A. and B.C. Kostyk. 2014. Soil drench applications of insecticides for control of Asian citrus psyllid and citrus leafminer, 2013. Arthrop. Mgt. Tests 39, doi: 10.4182/amt.2014.

Tansey, J.A., M.M. Jones, P. Vanaclocha, J. Robertson, and P.A. Stansly. 2015. Costs and benefits of frequent low-volume applications of horticultural mineral oil for management of Asian citrus psyllid Diaphorina citri Kuwayama (Hemiptera: Psylloidea). Crop Prot. 76:59-67.

Tiwari, S., R.S. Mann, M.E. Rogers, and L.L. Stelinski. 2011. Insecticide resistance in field populations of Asian citrus psyllid in Florida. Pest Mgt. Sci. 67:1258-1268.

Van den Berg, M.A., A.S. Dippenaar-Shoeman, V.E. Deacon, and S.H. Anderson. 1992. Interactions between citrus psylla, Trioza erytreae (Hemiptera: Triozidae) and spiders in an unsprayed citrus orchard in the Transvaal Lowveld. Entomophaga 37:599-608.

Xiao, Y., J.A. Qureshi, and P.A. Stansly. 2007. Contribution of predation and parasitism to mortality of citrus leafminer Phyllocnistis citrella Stainton (Lepidoptera: Gracillariidae) populations in Florida. Biol. Control 40:396404. 